\title{
EU and EPC prepare for patent fight
}

The European Directive on the Patenting of Biotechnology Inventions (the directive) is widely expected to pass the European Parliament (Strasbourg, France) in early summer. That will mark the end of a 10-year gestation period for this legislation, which is intended to harmonize patenting practice within the European Union (EU). It will also signal the beginning of a new struggle- to resolve the new directive with the European Patent Convention (EPC), the governing code of the European Patent Office (EPO; Munich); significantly, the EU has no direct jurisdiction over the EPO.

The most pertinent discrepancy between the two pieces of legislation is that Article 53b of the EPC expressly forbids patents on plant and animal varieties whereas the directive allows them. "The directive grants patent protection for a certain characteristic in plants or plant varieties," says Peter Lange, head of the legal department at KWB Kleinwanzlebener Saatzucht (Einbeck), Germany's largest plant genetic engineering company. Article $1 \mathrm{~b}$ (ii) of the directive states that "inventions whose object are plants or animals may be patented if the practicability of the invention is not technically confined to a particular plant or animal variety."

Lange insists that the two pieces of legislation would not be at odds if the appeals division of the EPO, the Technical Appeal Board (TBA), had "correctly interpreted Article 53b." However, in a 1995 landmark ruling, the EPO board ruled against issuing a patent covering the process for preparing herbicide-resistant plants to Plant Genetic Systems (PGS, now part of the Schering-Hoechst joint venture, AgrEvo; PGS is in Gent, Belgium). It granted PGS a patent covering the preparation of plant cells by the same method but argued that patents on the transgenic plants themselves were not allowable because Article 53b forbade dual protection (patents and variety rights).

Patents on plant cells can be useful, but industry would really like patents on the end products, the plants. "The patent for a transgenic cell is sufficient to file a suit for patent infringement," says Elke Simon, head of patents at AgrEvo (Frankfurt): "[but] in many situations it would be difficult to prove that the patented technology had been used."

Ideally, industry representatives would like simply to remove the offending article. "It would certainly be desirable to delete Article 53b," says Brian A. Yorke, head of Corporate

Ingeborg Fürst is a freelance writer working in Munich, Germany.
Intellectual Property at Novartis (Basel, Switzerland). "Furthermore, deletion of the whole article [including the exclusion from patenting of "essentially biological" processes] would bring protection up to the standards in the USA." However, such a simple fix is unlikely: The probability that patent protection for varieties will be allowed under the EPC "is next to nothing within the following 2 years," says Christian Guggerell, the director of examinations in genetic engineering at the EPO. Making such a change would be tantamount to drafting a new convention, he says, and that could not be approved quickly.

Any new convention would have to be ratified by the parliaments of all EPC signatory states. Even within the European Union, where national legislation will be bound by the directive, certain countries may not approve a new convention. Denmark, for example, has granted no patents on transgenic animals at all and is unlikely to ratify a convention that enables that to occur. EPC signatories outside the European Union, such as Norway, Switzerland, and some of the Eastern European nations, may also not welcome any change to the EPC.

The European Patent Convention can be changed through an "Implementing Regulation," which can be simply inserted following agreement among the EPC's governing board. However, Implementing Regulations cannot be used to add rules that obviously run counter to existing EPC provisions. Another route for changing the EPC could be revision of provisions by "Diplomatic Conference" among the signatories of the convention. But this is a long negotiating process that insiders say could take at least 5 years and still not succeed.

Thus, impasse is the most likely consequence of the clash of patent regulations. For several years, there are likely to be two different

sets of rules on the patenting of transgenic plants and animals in Europe. The EPO and European Commission cannot ignore the situation. Peter Lange believes that the EPO may agonize over changing its rules but, in the long run, "political pressure will bring the EPO into line with the directive."

The difficulties in resolving the two documents will not be helped by the lack of clarity in some of their working. For instance, the draft patent directive introduces the concept of the "plant grouping" to refer to the set of plants to which a given patentable invention may apply. The plant grouping is thus characterized by a particular gene. A plant grouping is patentable, even though its members may be new plants varieties that, individually, are not patentable.

Some of these issues may be resolved this autumn when matters that arose in an appeal case brought by Novartis come before the EPO's highest appeal authority, the Enlarged Board of Appeal. Among other questions, the company's lawyers are asking whether they can circumvent the Article 53b ban on patenting plant varieties if they avoid mentioning specific plant varieties in their claims--even though the claims they do make would implicitly encompass varieties.

However, in the original appeal back in October 1997, the lower appeal authority of the EPO, the 'TBA, had implied that Novartis' lawyers were indulging in wishful thinking when pursuing this argument. Novartis, the TBA statement said, had put forward an "unnatural interpretation" in suggesting that Article $53 \mathrm{~b}$ prohibited patents on single varieties but allowed a single patent that covered more than one variety. This argument, the TBA continued, would be like deducing from a law that said "bigamy is forbidden" that "polygamy is permitted."

Ingeborg Fürst

\section{Pharming cloning ban could spread}

The Dutch government's ban on nuclear transfer experiments at Pharming (Leiden, The Netherlands) could have implications for animal cloning across the whole of Europe. On February 17 of this year, two nontransgenic female calves cloned by nuclear transfer were born on a farm

Ellen Peerenboom is a freelance writer working in Cologne, Germany. belonging to Pharming. Just 9 days later, Van Jozias Aartsen, the Dutch Minister of Agriculture, introduced a temporary ban on further nuclear transfer experiments. The Dutch Society for Animal Protection (Amsterdam) welcomed the decision. In a statement, it said "this is the first time that a company has been prevented from doing what they want to do by the government for ethical reasons. It is a pity that this ban $\mathrm{did}$ not come earlier." 